The University of San Francisco

USF Scholarship: a digital repository @ Gleeson Library |

Geschke Center

Media Studies

College of Arts and Sciences

$10-8-2014$

\title{
Technologically Mediated Artisanal Production
}

Tamara Kneese

University of San Francisco, tkneese@usfca.edu

Follow this and additional works at: https://repository.usfca.edu/ms

Part of the Communication Technology and New Media Commons, and the Work, Economy and Organizations Commons

\section{Recommended Citation}

Kneese, Tamara, "Technologically Mediated Artisanal Production" (2014). Media Studies. 17.

https://repository.usfca.edu/ms/17

This Article is brought to you for free and open access by the College of Arts and Sciences at USF Scholarship: a digital repository @ Gleeson Library | Geschke Center. It has been accepted for inclusion in Media Studies by an authorized administrator of USF Scholarship: a digital repository @ Gleeson Library | Geschke Center. For more information, please contact repository@usfca.edu. 


\title{
Technologically Mediated Artisanal Production
}

\author{
by Tamara Kneese, Alex Rosenblat, and danah boyd \\ Data \& Society Working Paper, October 8, 2014 \\ Prepared for: Future of Work Project supported by Open Society Foundations
}

\section{Brief Description}

As traditional mass manufacturing in the tech, textile, and auto industries has largely left the United States and relocated to the Global South, post-industrial forms of work have taken the place of this kind of labor. And yet, the disappearance of manufacturing jobs and the dire straits of formerly great Rust Belt cities like Detroit have led to a kind of nostalgia for both industrial and artisanal modes of production. Manufacturing still exists in the United States, but there is movement towards a new kind of labor process and product. For example, industries like 3D printing and maker/hacker culture, which emphasize individual creativity as well as open source technology and collaboration, have been growing steadily. In these ecosystems, programming and tinkering are the new craft skills needed to perform this kind of labor and many everyday objects, both esoteric and functional, can be printed at home rather than being produced in a factory and later purchased at a store. Meanwhile, there is also nostalgia for hands-on work in the form of artisanal production, handmade objects, and DIY culture, which eschew new technologies and return to older ways of making. In some cases, these two new production sensibilities collide, as in the case of the artisanal and handmade but also 3D printed objects for sale on websites like Etsy and Shapeways. Maker Faires, a community gathering of makers and fans, in many ways combine artisanal nostalgia with automated, desktop manufacturing or 3D printing-and their associated techno-utopian connotations. While the DIY and maker movement have made some attempts at inclusion with regard to people of different races, ethnicities, socioeconomic backgrounds, genders, and sexual orientations, the majority of self-identified Makers are middleclass white men. How can these practices become more accessible to a wide variety of individuals? How can makers, hackers, and DIY aesthetes appreciate particular labor processes without turning a blind eye to structural inequalities and the harms of gentrification?

\section{History of the DIY Movement}

While it originated in $19^{\text {th }}$ century Britain, the American Arts and Crafts movement gained popularity at the turn of the $20^{\text {th }}$ century. The movement formed in response to ornate Victorian culture and marked a return to simpler or more rustic styles (Boehm, 
1990). After the Industrial Revolution of the $19^{\text {th }}$ century, some artists and craftspeople decried the use of machines in the making process. Rather than focusing on the industrial mass production of goods, Arts and Crafts proponents attempted to return to handicraft designs. Those involved in the movement produced new architectural styles, ceramics, and Mission Style furniture, in addition to other artisanal objects. Unlike the British model of Arts and Crafts, however, the American movement also mass produced these artisanally designed products and made them affordable to the middle class (Boehm, 1990). The Arts and Crafts movement was popular enough to spawn magazines devoted to it, such as The Craftsman and Handicraft.

The Arts and Crafts movement was in many ways an aesthetic one, but there were also individuals who clamored for a more political orientation: "The movement was concerned with promoting good taste and self-fulfillment through the creation and the appreciation of beautiful objects; its more radical wing also sought to advance worker autonomy" (Morozov, 2014). While many people appreciated the aesthetics of the Arts and Crafts movement, most workers did not have the time or space for artisanal production because they were confined to the mill or factory instead. Not everyone had the ability to leave a full-time job and produce handmade objects rather than buying ones earned with wages. The promise of worker autonomy afforded by the artisanal return was largely an empty one.

DIY culture continued throughout the early to mid $20^{\text {th }}$ century, but it was not part of popular discourse again until the countercultural 1960s, when several movements converged. Fred Turner (2008) outlines how the countercultural elements of the 1960s, combined with the birth of the personal computer, led to the birth of Stewart Brand's Whole Earth Catalog. Through the purchasing of a personal computer, individuals could become "hackers," part of underground culture. Brand advocated purchasing a woodburning stove and an Apple computer, a marriage of the rustic and the technological: "The way to join the holy disorder of hackerdom was by, say, playing Tetris-and, on weekends, going home and hacking rubber stamps, postcards, and whatever else one had ordered from the 'Whole Earth Catalog'" (Morozov, 2014). In the 1960s, a new kind of entrepreneurialism and techno-utopianism comingled with a rustic, DIY ethos.

This ethos lived on during the 1970s and 1980s, but it was largely the purview of punks and other underground, countercultural types (Permanent Culture Now, 2004). In the 1990s, anti-globalization efforts and the return of widespread countercultural movements combined with the dotcom boom to create an atmosphere ripe for a new DIY aesthetic. In their introduction to DIY Citizenship: Critical Making and Social Media, Matt Ratto and Megan Boler assert that contemporary DIY culture is intimately entwined with new technologies, especially social media and other communication platforms. They argue that DIY citizenship "can be understood as a twenty-first century amalgamation of politics, culture, arts, and technology that in turn constitutes identities rooted in diverse making practices" $\left(2014\right.$, p. 18). While the book's focus is on the $21^{\text {st }}$ 
century, social media, and maker culture, these issues are also historically based. Many of the same tensions between consumerism and utopian forms of collectivity and citizenship surface in current debates, echoing the problems of the Arts and Crafts movement of the $19^{\text {s }}$ and early 20th centuries, or the countercultural but entrepreneurial spirit of the Whole Earth Catalog in the 1960s.

Today, the relationship between self-sufficiency and technology continues. While the Whole Earth Catalog faded into obscurity, it has recently been resurrected by Wired co-founder Kevin Kelly, demonstrating that the DIY aesthetic is indeed back.

\section{$\underline{\text { Rise of 3D Printing as Techno-utopianism }}$}

3D printing first emerged as a new technology in the 1990s. Since the mid 2000s, there has been growing interest in this technology, as more companies begin to offer models and 3D printers that attract attention for their ability to produce clothing, furniture, artificial limbs, organs, guns, and food. The basic 3D printing process works as follows: "Today, 3D Printers have evolved to make a variety of objects using a laser or extruder (the material output part of the printer, best described as a futuristic hot glue gun) that move along an $\mathrm{X}, \mathrm{Y}$ and $\mathrm{Z}$ axis to build an object in three dimensions, layer by layer, sometimes only microns thick at a time, depending on the desired resolution of the object" (Hart, 2012). The printers have become relatively affordable, with some models starting as low as \$500, and DIY kits from companies like RepRap enable enterprising individuals to build their own units (Hensley \& Kneese, 2013). As Hugh Evans (2012), the vice president of T. Rowe Price Associates, speculated in Popular Science, 3D printing is a "game changer" because the falling price of printers means that "the marketplace opens up to individuals like us. It could be as soon as three years from now that people will have a 3D printer at home to make toys, napkin holders, curtain rings, and whatever is needed."

From the onset, 3D printing has been associated with techno-utopianism because of its relationship to the open source movement, its inherently DIY sensibilities, and its supposed potential to solve a number of pressing social and biological problems. Chris Anderson, the former editor-in-chief of Wired, recently published a book on the "maker movement," a particular branch of DIY culture closely tied to MakerBot and other 3D printing companies that use open source software. In Makers: The New Industrial Revolution, Anderson champions 3D printing, viewing it as a burgeoning technology that will revolutionize the world. He and likeminded technophiles have gone so far as to claim that 3D printing will jumpstart another industrial revolution. On the website for

\footnotetext{
${ }^{1}$ For more on 3D printed clothing, see Duann's (2013) “Revealing Dita Von Teese in a Fully Articulated 3D Printed Gown." For 3D printed guns, see: Andy Greenberg's (2014) “How 3-D Printed Guns Evolved Into Serious Weapons in Just One Year." For 3D printed food, see Polly Mosendz' (2014) "3D-Printed Food Actually Looks (and Tastes) Pretty Delicious." For 3D printed organs, see: Brandon Griggs' (2014) “The next frontier in 3-D printing: Human organs." For 3D printed limbs, see: Anna Leach's (2014) “3D printed prosthetics: long-term hope for amputees in Sudan."
} 
Anderson's book (Makers, 2012), a promotional emphasizes this point: Now that manufacturing in the United States has all but disappeared, "[t]he solution, Anderson says, is in a desktop manufacturing revolution that will change the world as much as the personal computer did. The tools of factory production, from digital fabrication to online factory services, are now available to everyone; garage start-ups can make products in batches as small as a single unit or as large as tens of thousands. Anyone with an idea can set assembly lines into motion with little more than a keystroke." 3D printing is thus seen as a democratizing force: small businesses are no longer reliant on the supply chain or corporate capitalism to produce their goods. Theoretically, anyone with an idea can design and make products. According to this logic, anyone can be a Maker.

The design website Freshome has dubbed 3D printing a "disruptive technology that is revolutionizing the manufacturing industry" (Stacey, 2012). According to Freshome, the revolutionary aspect of $3 \mathrm{D}$ printing is not just its ability to alter the actual production of products, but its imagination-provoking capacities: 3D printing "is an enabling technology that allows companies to think differently about their supply chains, and more importantly the value chain and interaction with the customers within their business" (Stacey, 2012). Companies can now produce a wide variety of products in small batches, customize them, and even engage consumers in the design process. Or for those with the skills and means to purchase or build and manipulate their own 3D printers, there is now a way to design and manufacture custom pieces at home. Not only is $3 \mathrm{D}$ printing technology associated with creative product design and production, but it's also considered to be a means for human beings to free themselves from the shackles of traditional manufacturing (Hensley \& Kneese, 2013).

$3 \mathrm{D}$ printing is also associated with futurist dreams of automation and obviating the need for human manufacturing, along with much of consumer capitalism: eventually, we will outsource the labor to self-reproducing machines in the comfort of our own homes and have more time for ourselves. For example, Jaron Lanier claims that "[i]n a humanistic digital economy designers will still make a living, even when a dress is sewn in a home by a robot" $(2013$, p. 260). From this perspective, automation is not seen as a threat to human jobs because people will still do the creative design work-even if robots do the actual production work. For Lanier, 3D printing is part of this possible future world. Because 3D printers have now been used to produce artificial limbs, organs, and even food, they are also associated with an ability to solve many of the world's ills, such as protecting against global inequalities and reducing industrial waste (Wong, 2014).

Although 3D printing is touted as democratizing, there are serious ecological risks and immense social changes connected to the plastic materials used to make 3D-printed objects (Armstrong, 2014). While the printers can produce these objects in a wide variety of materials, the vast majority of things produced are plastic trinkets, which can have a negative environmental impact. Furthermore, 3D printers require massive amounts of 
energy and also pose air quality issues because of their emissions problems (Gilpin, 2014b).

3D printers are not just used by hobbyists at home or by niche markets of technophiles, but are being implemented as part of the global economy: The 3D printing industry will undoubtedly have far-reaching effects. According to the McKinsey Global Institute, "3D printing will cause major disruptions in the global economy by 2025" (Gilpin, 2014a). According to the McKinsey report, 3D printers will accelerate prototyping, allowing new models to reach consumers faster, and vastly lower the cost of production, both when it comes to materials and labor power. Companies could cheaply print large sums of new parts themselves rather than relying on other industries to ship them individual parts. These printers will have a widespread effect on numerous industries and change global manufacturing and supply chains, potentially displacing many workers. Cheese, pizza, eggplant, and other food items have been successfully printed, meaning that 3D printing could eventually impact the food production and service industries. If 3D printing is used to manufacture automobile parts and whole cars, this could displace auto plant workers (Ehrlich \& Fu, 2013). While 3D printing has the ability to make some forms of manufacturing more democratic, it may exacerbate global structural inequalities in others ways. In this way, maker culture is indeed connected to a new industrial revolution.

\section{Artisanal Nostalgia}

Another response to the disappearance of manufacturing from the US landscape and the growth of automation is the resurgence of artisanal production. For anyone who has traveled to Brooklyn or watched an episode of Portlandia, a yearning for the 1890s is apparent (Krisel, 2011). Beards, bourbon, pickles, suspenders, artisanal mustard, smallbatch production and handmade goods in general are all the rage and have come to define urban enclaves as places for young aesthetes. Cities like Seattle, Portland, Brooklyn, San Francisco, Chicago, and Austin have become epicenters of this artisanal turn. But this is not just a return to old ways of life. Rather, it marks a new era where futurism and the techno-utopian combine with a kind of nostalgia for pre-Fordist and pre-industrial methods of making. In many of these urban centers, there is both a booming tech industry and a growing techno-utopianism in direct connection with this return to older modes of craft production, as will be elucidated in the next section.

Although artisanal practices extend beyond the city, the media frenzy around the return of the handmade is largely based on changes in urban centers. Critics have argued that this kind of nostalgia ignores issues of race, poverty, and gentrification in places like Brooklyn. Writing for Jacobin, Laura Tanenbaum (2014) notes that "[b]ike culture, local food culture, and artisanal culture attempt to connect hipsters to the neighborhoods they're accused of gentrifying. Relentlessly local even as Brooklyn becomes a global brand, this strain has much in common with the earlier, civically minded generation of brownstoners." While neighborhoods in Brooklyn, like the areas 
of Williamsburg and Greenpoint, are associated with this artisanal turn, one quarter of Brooklynites receive food stamps, which raises eyebrows at how artisanal nostalgia is also tied to patterns of inequality and gentrification (Kotkin, 2012).

Not all of this DIY revivalism is urban-based, however, as there has also been a resurgence of homesteading and organic farming; young urban professionals may also try their hand at raising goats or making artisanal cheese in the country. Websites like the Prairie Homestead and Survival Life focus on rural interpretations of artisanal production (Winger, 2013; Jackson, 2014). The New York Times has featured a series of articles about young, urban, educated professionals who renounce corporate life to become organic farmers (Salkin, 2008). Recently, some of these young farmers lamented the difficulties of making any profit when Community Supported Agriculture has become competitive (Smith, 2014).

Analyzing artisanal cheesemaking practices in The Life of Cheese, Heather Paxson reveals the multitudes of conflicting values that underpin farmer's markets, the construct of organic, the artisanal movement, and the rise in desire to produce food locally. Most notably, she highlights the ways in which artisanal practices are often not self-sustaining because even wealthy urban consumers who are obsessed with artisanal culture are not willing to pay what it takes for an independent farmer to truly earn a reasonable wage. For small-scale farmers attempting to raise truly "happy chickens," with plenty of roaming space and an organic, grain-free diet, the real consumer cost of a dozen eggs could be upwards of $\$ 12$ if the farmers were to make any profit, or just break even (Hyde, 2014). Are even the most ardent locavores willing to spend this in order to ensure their farmers receive a living wage? In unpacking what's at stake, Paxson highlights the ways in which artisanal practices obscure significant financial inequities that raise cultural and ethical issues about the phenomenon.

\section{Makers and the Automated Handmade}

Some cultural critics and scholars have noted that the return to the handmade or artisanal is often combined with the techno-utopian narratives surrounding phenomena like 3D printing. For instance, the maker movement marks a marriage between these two seemingly incongruous aspects of post-industrial production, combining a DIY sensibility with new technologies. While DIY culture used to apply to fixing up one's own house or learning to sew one's own clothes, now it often refers to movements like the one started by makers. Not only are makers now considered a community, but they are attracting the attention of major corporations and traditional industries: "With so many people able to freely share ideas and spread inspiration across the web, makers are forming communities of their own, and more people around the world are becoming influenced to be makers. Etsy now has over one million artisan sellers who have created handmade products to be sold on the site. (The site also did nearly a billion dollars in revenue last year, clearly indicating there is also extremely high demand for these handmade goods.)" (Morin, 2013). The Maker Faire is also an important part of this new 
maker culture, where thousands of people come together to share their 3D printed or DIY goods with one another. There are annual Maker Faires in many major cities, and these events draw hundreds of thousands of people, including heads of industry: "At the San Mateo Maker Faire were companies like Intel, Nvidia, AMD, AutoDesk, Oracle/Java, Ford, NASA, Atmel, Qualcomm, TI, 3D Robotics and many more that see this movement as important and want to support it" (Bajarin, 2014). While makers are associated with self-reliance and individual entrepreneurialism, large corporations are interested in bringing these new forms of production back into mainstream industry practices.

The Maker Faire is an excellent site for examining the crossover between artisanal nostalgia and 3D printing techno-utopianism. At these Faires, items found at a farmer's market, the Renegade Craft Fair, and a hackathon collide: "While its roots are techrelated, there were people at the show teaching how to crochet, make jewelry, and even one area called Home Grown, where do-it-yourselfers showed how to pickle vegetables, can fruits and vegetables, as well as make jams and jellies. There was another area focused on eco-sustainability, bee keeping, composting and growing your own food" (Bajarin, 2014). Much like the early Arts and Crafts movement in the United States, the maker movement has its own magazine, called Make, in addition to the Maker Faires. Like the movement in the 19 ${ }^{\text {t }}$ century, makers offer an antidote to the mass produced plastic trinkets offered by China: "Makers tap into an American admiration for selfreliance and combine that with open-source learning, contemporary design and powerful personal technology like 3-D printers. The creations, born in cluttered local workshops and bedroom offices, stir the imaginations of consumers numbed by generic, mass-produced, made-in-China merchandise" (Voight, 2014). Even if they are made of plastic or printed by automated systems, these objects strike consumers as more authentic than imported items.

Also like the artisanal production central to the Arts and Crafts movement of the $19^{\text {th }}$ and early 20 $0^{\text {th }}$ century, many of these artisanal products can be and are mass-produced. Etsy defines machine-made products as handmade because if the design is done by an individual, that is all that matters (3Ders, 2013). The idea that these goods are handmade in spirit is key. In fact, programming knowledge is required to make these objects. One must learn how to design and program everything, including what will create the "authentic" looking dings and imperfections that are intrinsic to actual handmade gifts. For example, a company in Belgium produces artisanal pottery using a 3D printer, and programs imperfections directly into their designs (Summerson, 2012). That's why a lot of makers gravitate toward companies like Shapeways, which handles the actual printing. While individuals may design the product, they need not actually manufacture it themselves. Instead, they upload their model to Shapeways and choose a material. Shapeways prints it and ships it out as a customized order. Those who lack the skills to create with their hands or do not have training in artisan crafts can approximate these forms of embodied practice through programming skills, or by using technologies offered by the Shapeways (2014) interface: "Simply type or drag your mouse to make 
stuff, and hold it in your hands in days. Creating has never been easier." While designing the objects requires specific expertise and programming knowledge or skill sets, the production is outsourced to machines owned and produced by the Shapeways company. Also, once a product exists in design form, it can be reproduced infinitely in a wide range of materials: yes, a unique art object can actually be mass-manufactured. While the objects are not handmade in literal terms, they take on the same value as DIY and craft commodities sold on websites like Etsy. Part of these objects' appeal is that they are embedded with the aura of DIY authenticity, and yet when they are sold on the market they are no longer for "yourself" but for consumers-another way that 3D printing further blurs the boundaries of DIY and mass production (Hensley \& Kneese, 2013).

In his article "A more lovingly made world," McKenzie Wark discusses the logics behind the Maker Faire. He praises the fact that maker culture "puts traditionally male and female kinds of amateur hobby stuff side by side," rather than, for example, dividing male hackers from female knitters. But Wark also notes that despite the name of the movement, much of it is not actually about making anything: "It's like a homey version of what Nicholas Bourriaud called 'postproduction art.' The Stuff has already been made, you put it together. Like Ikea furniture, but, you know, fun. It probably isn't fun working in the factories that makes the circuit boards or the Lego bricks or the knitting machines."

According to Wark, there is a kind of fetishistic quality to the Maker Faire because the making process is still hidden. Much of the actual physical labor, like the production of circuit boards, the components of the 3D printers themselves, and the filament spools used to produce printed goods, is done overseas by underpaid and overworked individuals. Wark explicitly connects the Brooklyn artisanal food movement to the notion of maker culture. In Brooklyn food culture, the focus is on the labor process itself, but on a very individual level, with an eye on the artisan's skills. We rarely see actual manual labor, like that of the dairy farmers who provide raw goods to cheesemakers, because of our cognitive labor jobs and the extreme division of work. So the idea of making things, but not of the full process, becomes intriguing and acts as a kind of fetish. We only see the people cleaning our floors or making our lattes, and can only imagine those who are producing iPhones for Foxconn or making the plastic spools that fit in 3D printers. How might we begin to address some of the inequalities associated with artisanal production and 3D printing? How might these new movements be used to alter the face of entrepreneurialism and manufacturing on a global scale? What sorts of workers might be displaced by 3D printing and increased automation? What sorts of skills and expertise will be valuable in the future?

While makers and 3D printing are supposedly part of an industrial revolution and democratizing force, the makers are still in many ways a niche market. For instance, "According to a survey conducted by Maker Media, 8 out of 10 Makers are male. Their median age is 44 . Their average household income is $\$ 106,000$. Nearly 83 percent are 
employed, and 31 percent have job descriptions that fall into scientific or engineering categories. 97 percent are college graduates and 80 percent have some post-graduate education" (Leonard, 2013). This lack of diversity in the maker movement is a mirror of general Silicon Valley disparities, where women and minorities are severely underrepresented (Weise, 2014). Maker movement proponents, however, have made efforts to include more women and minorities, as well as to highlight the achievements of women, African Americans, and members of the LGBTQ+ community in the tech world. The website Maker Bridge lists groups, organizations, individuals, and resources related to African American makers, women makers, and LGBTQ+ makers (Maker Bridge, 2014). While members of different minority groups do participate in maker culture, Maker Bridge attempts to make them more visible. How might these less visible members of the maker movement feel more included? How can the tech industry in general become a safer space for these groups?

Women may be underrepresented in the maker movement, but they are the face of the DIY, modern homesteader movement, where women blog about cooking rustic dishes and sewing their family's clothes. These women may not actually be selfsufficient, however, and have forms of economic privilege that allow them to take part in this form of lifestyle politics. As noted by Ryan-Ashley Anderson (2014), "[f]or most mommy-bloggers, their "rustic" DIY lifestyle is often sustained not by the money they bring home from selling their canned goods at the quaint farmers market down the street, but by their husband's income." The self-reliance and back-to-the-earth ethos touted by the DIY homesteader movement is in fact dependent on these types of economic arrangements. As demonstrated by the financial hardship faced by small-scale farmers, the DIY lifestyle may not be sustainable for most people, especially for those who are already economically vulnerable. What role does structural inequality play in the very formation of the DIY homesteader lifestyle? How can we better address problems like gentrification, racial inequality, the reinforcement of traditional gender roles, and wealth disparity when we talk about the maker and DIY movements, 3D printing, and the tech industry in general? Are there political or legislative solutions to these problems?

\section{Acknowledgments}

This document was produced as a part of the Future of Work Project at Data \& Society Research Institute. This effort is supported by the Open Society Foundations' U.S. Programs Future of Work inquiry, which is bringing together a cross-disciplinary and diverse group of thinkers to address some of the biggest questions about how work is transforming and what working will look like 20-30 years from now. The inquiry is exploring how the transformation of work, jobs and income will affect the most vulnerable communities, and what can be done to alter the course of events for the better.

We are grateful to Patrick Davison, Tim Hwang, Rosa Jurjevics, Karen Levy, and Seth Young for their help with different aspects of this project. 


\section{Bibliography}

3Ders. (2013). “Etsy: 3D printed items are 'Handmade In Spirit.'” 3Ders.org, November 18, 2013. http:/ / www.3ders.org/articles / 20131118-etsy-3d-printed-items-are-handmade-in-spirit.html Anderson, Chris. (2012). Makers: The New Industrial Revolution. New York, NY: Crown Business.

Anderson, Ryan-Ashley. (2014). "Pinterest Fantasies and the Homesteading Dream: Where Does the DIY Woman Belong Today?" ETHOS, April 30, 2014.

http:/ / www.ethosreview.org/cultural-interventions/ pinterest-fantasies/

Armstrong, Rachel. (2014). "3D Printing Will Destroy the World Unless It Tackles the Issue of Materiality." The Architectural Review, January 31, 2014. http:/ / www.architecturalreview.com/home/products/3d-printing-will-destroy-the-world/8658346.article

Bajarin, Tim. (2014). "Why the Maker Movement Is Important to America's Future." Time, May 19, 2014. http: / / time.com/104210/maker-faire-maker-movement/

Boehm, Mary Dutton. (1990). "The Arts and Crafts Movements in America." The Journal of San Diego History, 36(2 \& 3), 1990. http:/ / www.sandiegohistory.org/journal/90summer/arts.htm

Duann. (2013). "Revealing Dita Von Teese in a Fully Articulated 3D Printed Gown." The Shapeways Blog, March 5, 2013. http:/ / www.shapeways.com/blog/archives/1952-RevealingDita-Von-Teese-in-a-Fully-Articulated-3D-Printed-Gown.html

Ehrlich, Thomas \& Ernestine Fu. (2013). "Our Future with 3D Printers: 7 Disrupted Industries." Forbes, October 29, 2013. http:/ / www.forbes.com/sites/ehrlichfu/2013/10/29/our-futurewith-3-d-printers-7-disrupted-industries/

Evans, Hugh. (2012). "3D Printing is a Game Changer." Popular Science, August 27, 2012. http://www.popsci.com/sponsored-article-t-rowe-price

Gilpin, Lyndsey. (2014a). "10 industries 3D printing will disrupt or decimate." TechRepublic, February 12, 2014. http:/ / www.techrepublic.com/article/10-industries-3d-printing-willdisrupt-or-decimate /

Gilpin, Lyndsey. (2014b). “The dark side of 3D printing: 10 things to watch." TechRepublic, March 5, 2014. http: / / www.techrepublic.com/article/ the-dark-side-of-3d-printing-10-things-towatch/

Greenberg, Andy. (2014). "How 3-D Printed Guns Evolved Into Serious Weapons in Just One Year." Wired, March 15, 2014.http:// www.wired.com/2014/05/3d-printed-guns/

Griggs, Brandon. (2014). "The next frontier in 3-D printing: Human organs." CNN Tech, April 3, 2014. http:/ / www.cnn.com/2014/04/03/tech/innovation/3-d-printing-human-organs/

Hart, Brad. (2012). “Will 3D Printing Change The World?” Forbes, March 6, 2012. http:/ / www.forbes.com/ sites/gcaptain/2012/03/06/ will-3d-printing-change-the-world/

Hensley, Kari \& Tamara Kneese. (2013, May). “3D Printing as Futurist Nostalgia.” Paper presented at the Cultural Studies Association's Annual Conference in Chicago, IL, USA.

Hyde, Bill. (2014). "The Real Cost of Food." The Weston A. Price Foundation. http:/ / www.westonaprice.org/health-topics/the-real-cost-of-real-food /

Jackson, Lauren. (2014). “9 Unique DIY Homesteading Projects.” Survival Life, March 3, 2014. http:/ / survivallife.com/2014/03/03/9-unique-diy-homesteading-projects /

Kotkin, Joel. (2012). "The Hollow Boom of Brooklyn: Behind Veneer of Gentrification, Life Gets Worse for Many." Forbes, September 25, 2012. http:/ / www.forbes.com/ sites/joelkotkin/2012/09/25/the-hollow-boom-of-brooklynbehind-veneer-of-gentrification-life-gets-worse-for-many / 
Krisel, Jonathan (Director) \& Fred Armisen, Carrie Brownstein, Jonathan Krisel, Jonathan, \& Allison Silverman (Writers). (2011). Dreams of 1890. In Portlandia. Portland, OR: IFC.

Leach, Anna. (2014). “3D printed prosthetics: long-term hope for amputees in Sudan.” The Guardian, June 13, 2014. http:/ / www.theguardian.com/global-development-professionalsnetwork/2014/jun/13/3d-printing-south-sudan-limbs

Leonard, Andrew. (2013). “The maker economy can't fix everything.” Salon, July 26, 2013. http:/ / www.salon.com/2013/07/26/the_maker_economy_cant_fix_everything/

Makers. (2012). "About Makers." http:/ / www.makers-revolution.com/\#about-makers

Maker Bridge. (2014). "Inclusivity and LGBTQ+ Participation in Maker Culture." Maker Bridge Blog. Accessed October 1, 2014. http:/ / makerbridge.si.umich.edu/blog/140421-800

Morin, Brit. (2014). “What Is the Maker Movement and Why Should You Care?" The Huffington Post Blog, May 2, 2013. http:/ / www.huffingtonpost.com/brit-morin/ what-is-the-makermovemen_b_3201977.html

Morozov, Evgeny. (2014). "Making it." The New Yorker, January 13, 2014. http:/ / www.newyorker.com/magazine/2014/01/13/making-it-2

Mosendz, Polly. (2014). “3D-Printed Food Actually Looks (and Tastes) Pretty Delicious.” The Wire, May 29, 2014. http:/ / www.thewire.com/technology/2014/05/3d-printed-foodactually-looks-and-tastes-pretty-delicious / $371863 /$

Permanent Culture Now. (2004). "Introduction to DIY / Counterculture." http:/ / www.permanentculturenow.com/introduction-to-diy-counterculture /

Salkin, Allen. (2008). "Leaving Behind the Trucker Hat." The New York Times, March 16, 2008. http:/ / www.nytimes.com/2008/03/16/fashion/16farmer.html?pagewanted=all

Shapeways. (2014) “About." Accessed August 25, 2014. http:// www.shapeways.com/about Sheppard, Stacey. (2012). "How 3D Printing is Disrupting Mainstream Manufacturing Processes." Freshome, November 6, 2012. http:/ / freshome.com/2012/11/06/how-3d-printing-isdisrupting-mainstream-manufacturing-processes/

Smith, Bren. (2014). “Don't Let Your Children Grow Up to Be Farmers." The New York Times, August 9, 2014. http:/ / www.nytimes.com/2014/08/10/opinion/sunday/ dont-let-yourchildren-grow-up-to-be-farmers.html?_r=0

Summerson, Karen. (2012). "Belgian Studio Creates Artisanal 3D Printed Pottery." PSFK, October 19, 2012. http: / / www.psfk.com/2012/10/artisanal-3d-printed-pottery.html - !bKM3rZ

Tanenbaum, Laura. (2014). "My Brooklyn, Not Yours." Jacobin, 13. https: / / www.jacobinmag.com/2014/01/my-brooklyn-not-yours/

Turner, Fred. (2008). From Counterculture to Cyberculture. Chicago, IL: University of Chicago Press. Voight, Joan. (2014). "Which Big Brands Are Courting the Maker Movement and Why." AdWeek, March 17, 2014. http:/ / www.adweek.com/news/advertising-branding/which-big-brandsare-courting-maker-movement-and-why-156315

Wark, McKenzie. (2013). "A more lovingly made world." Cultural Studies Review, 19(1), 296-304. Weise, Elizabeth. (2014). "Tech: Where the Women and Minorities Aren't." USA Today, August 15, 2014. http:/ / www.usatoday.com/story/tech/2014/05/29/ silicon-valley-tech-diversityhiring-women-minorities/9735713/

Winger, Jill. (2013). "A collection of the best Do-It-Yourself tips and tricks from The Prairie Homestead." The Prairie Homestead. http:/ / www.theprairiehomestead.com/diy Wong, Vanessa. (2014). "A Guide to All the Food That's Fit to 3D Print (So Far)." Bloomberg Businessweek, January 28, 2014. http:/ / www.businessweek.com/articles/2014-01-28/all-thefood-thats-fit-to-3d-print-from-chocolates-to-pizza 